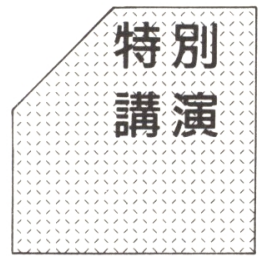

\title{
“紙”の将来と機能紙
}

機能紙研究会長

神戸女子大学教授 稲 垣

寛

\section{High performance paper in the perspectives of "paper" industries}

\author{
Hiroshi Inagaki \\ High Performance Paper Society, Kobe Women's University
}

紙パルプ技術協会が創立 40 周年を迎えられました ことを心からお祝い申し上げます。また本日お招き頂 きました事を厚くお礼申し上げます。

『21 世紀に向けて…」という大きなテーマの下で紙 の将来について充分なお話しが出来るかどうか, 誠に 危惧する次第ですが, ここでは未来の紙の中での機能 紙の役割について考えてみたいと思います。

はじめに

“紙”と書きましたのは, Paper like materials 又は 薄葉物という意味で, 次のようにフイルムから紙・不 織布・織物までを含むという意味であります。

“紙” (Paperlike Materials...紙様物質) について フイルム一合成紙厂紙一华合成㵶維紙(湿式丁乾式不織布一布 (第3の紙) 不織布) 其の他の織 (織物・編物) 高分子の 2 次展開維紙(金属, 無機䋐 (乾式) 糸の 物

(新素材)

膜

(Membrans) 維紙(
維) 維) 湿式法による繊維の 2
次展開物 次展开物

機能紙(High Performa次展開物 機能・差別化 nce Paper)

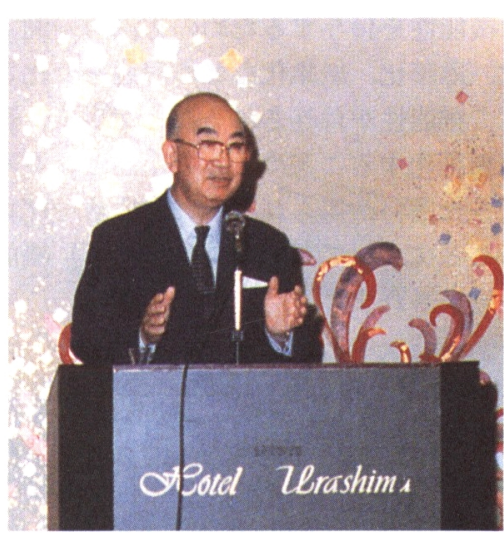

また紙の定義も時代とともに変化し, 戦前は天然繊 維を水中で絡らまして(抄く), 乾燥し, 強度をもたせ た薄葉物であったものが, 原料繊維に化学繊維, 合成 繊維を含み, さらに金属緎維, 無機繊維に拡がってき ており，今や紙は湿式法による繊維の二次元の展開物 と考えるのが妥当といえます。
1) 昭和 62 年 6 月 17 日，紙パルプ技術協会 創立40周年記念講演会 (東京ホテル浦島) におい て講演されたものである。

2）稲垣 寛氏のご紹介

昭和17年 ハルピン工業大学応用化学科卒業 昭和 22 年 $~ 36$ 年 京都大学工学部繊維化学教室 昭和 36 年 工学博士

昭和 36 年 $~ 50$ 年 昭和高分子(株専務取締役

昭和51年 神戸女子大学家政学部教授 機能紙研 究会長 現在に至る。
高分子化学が専攻で, 合成繊維紙 (ピニロン紙) PVA 繊維状バインダー, その他紙加工用樹脂な どの研究, 開発に携わる。

従来の“紙”に新なな機能を付与した紙「機能紙」 研究会の会長として紙先端技術の研究でご活躍中 で

『特殊機能紙』(シー・エム・シー)

『合成樹脂エマルジョン』(高分子刊行会) などの編著書がある。 


\section{1. 紙の機能と機能紙}

\section{1）機能について}

機能の『機』は織機のたて系を上下させる部分の名 称で，働くとか動くことを意味しております。高度の 機能はフィードバック作用を持ったもの，高温になれ ば冷却し，速度が速くなれば停止したり，減速すると かの能力を備えたものをいい，最も巧妙に行われてい るのが生物現象といえます。エレクトロニクスやバイ オテクノロジーの分野では機能を文字通りに Function としてこのような働きととらえております。

しかし紙や接着烱, 塗料, 不織布などの分野ではもっ と低い機能…現在のものより付加価值を高めたもの… を指すのが普通であります。今年 (1987 年) の米国の TAPPIの不織布のコンファレンスも High performance nonwovens を副題としており, 我々の機能紙 研究会も英文名に High performance paper society を使用しております。

表 1 は機能性を付与するための方法の一例で，特に 微粉末化, 薄膜化, 繊維化などの形態を変化させるこ とによって機能性が付与されることが多く，高分子を 延伸させ繊維化することによって，高ヤング率で抗張 強度の大きな原料が得られ，それを薄層やブロックに 加工寸ることによって（紙や立体にする）機能の倍増, 三倍増が達成されます。

表 1 機能性の付与の一例

\begin{tabular}{|c|c|}
\hline 材質の改変 & $\begin{array}{l}\text { アモルファス, 高結晶化, ハイブリッ } \\
\text { ド, 化学構造… }\end{array}$ \\
\hline 純 粋 化 & 純水, 純粋ガス類 \\
\hline 不純物化 & 不純物半導体 \\
\hline 形態の変化 & $\begin{array}{l}\text { 微粉末, 超微粉末 ( } 10 \mathrm{~nm} \text { 以下) } \text { 表面 } \\
\text { 積の拡大, 表面性の変化… }\end{array}$ \\
\hline
\end{tabular}

薄膜化 $\cdots$ 皮膜 (フィルム)一膜 (メンブラン)，分子膜 繊維化…結晶化，ヤング率の向上，構造材としての 適性, 表面積の拡大, 断面の異形化

機能紙…緎維の二次展開，孔径のコントロール，㵶 維の性能との関係，新素材としての可能性

\section{2）紙の機能性}

図 1 は紙，フイルム，織物の抗張強度と伸びの測定 結果で, 結晶化度の低いフイルムや，糸と糸との間の ずれが生ずる織物に対して, 結晶化度の進んだ纎維か ら抄いた紙は抗張強度の上昇に対して伸びが急で，紙 が薄いのに剛直で，折り目がつき易い性質がよく表れ ています。

次に繊維化することによって，表面積が大になるこ

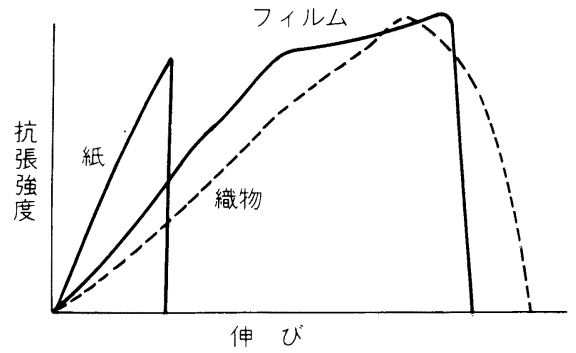

図 1 紙，フイルムの Strain-Stress Curve

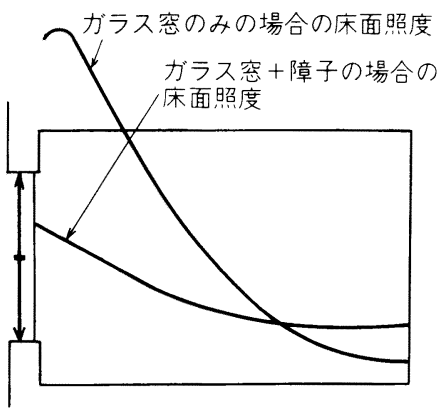

図 2 障子紙による採光の拡散効果 ${ }^{11}$

とで，図 2 は，ガラス空に障子紙を併用した時の明る さを測定したもので，ガラスだけの場合は空辺は非常 に明るいが奥は暗いのに対して，障子を入れることに よって，光線が纎維の表面に当たって乱反射するため， 空辺ではやわらかい明るさで，しかも奥まで光が届く 事で，日本の建物の奥にある床の間の掛軸が良く見え るなど，紙の原料繊維の機能をよく生かした例と云え ます。

第 3 は繊維の集合物である紙の最大の特長である緎 維間の空孔で，フイルムが $1 \AA \sim 100 \AA$ に対して，紙は $1 \mu \sim 100 \mu$ と大きいのに比べ，機能紙では繊維の選択 や皮膜の加工などにより $100 \AA \sim 1 \mathrm{~mm}$ 位の広い孔径 分布が得られております。

\section{3）紙への機能性の付与一機能紙}

従来は植物繊維内で， a ) 繊維の選択 b ）吒解度 c）抄紙方法・加工 などを工夫することにより機能 性が追求されており，それぞれの成果が得られてきま した。例えば，金䇴の製造にあたって，力のかかる初 めは楮紙を使用し，金䈃が薄くなると繊維の細く平た い㷳皮紙を用い，さらに灰を塗布し，打ち終った簿は みつまた紙の間に挟むなど，あるいはスピーカーの コーン紙にヤング率の高い，北洋材の冬材を使用する など，繊維を選ぶ事によって目的の機能を得ており, また吒解は紙の基本とまでいわれております。 
現在は原料繊維の選択範囲が著しく拡大し,さらに バインダー, 加工剤, 抄紙方法の進歩が機能紙を支え ております。

図 3 のように天然パルプでは $200^{\circ} \mathrm{C}$ 前後の耐熱性し か得られなかったものが, アルミ十繊維を使用するこ とにより $2000^{\circ} \mathrm{C} に も$ 耐えられる紙が製造されるよう になりました。また図4のように天然パルプより一桁 以上比弾性率が高い, アルミナ瀻維, ボロン繊維, カー ボン緎維からの紙は, 不飽和ポリエステルやエポキシ 樹脂をはじめ種々の樹脂の補強材として利用され, ま た高周波や高音の再生が良く, 騒音防止にも注目され ています。

逆に, 低ヤング率のコラーゲン繊維は低音再生用の スピーカーに有用であります。図 5 はコラーゲン繊維 を用いたコーン・スピーカーと紙との温度変化に対す る比較で, 紙が低温で高音域に移行するに対して, コ ラーゲン繊維を使用したものは安定性を示しています。

表 2 は各種の合成纎維を使用した紙の性質で, 原料 緎維の特性が紙の性質に強く影響しています。

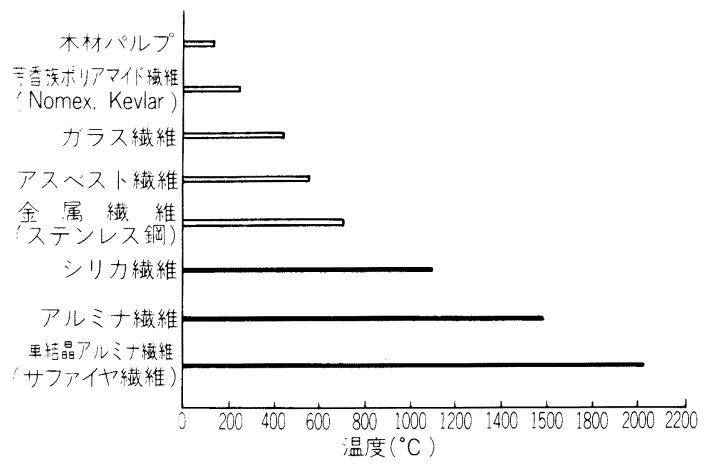

図 3 紙に使用される纎維の最高使用温度 ${ }^{2)}$

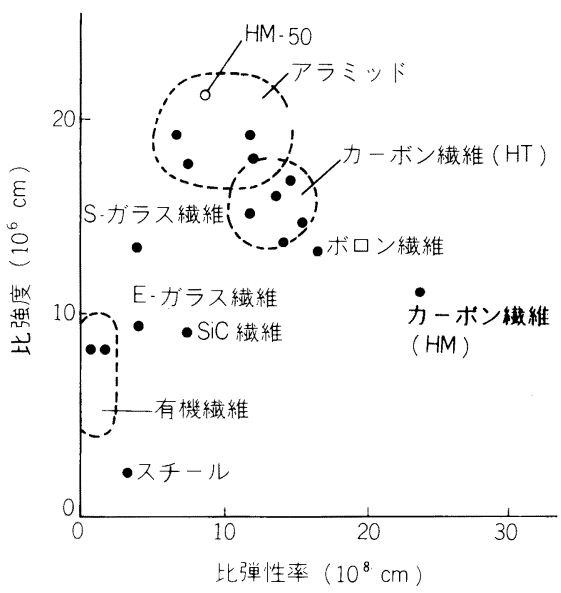

図 4 各種繊維の比強度一比弾性率特性 ${ }^{3)}$

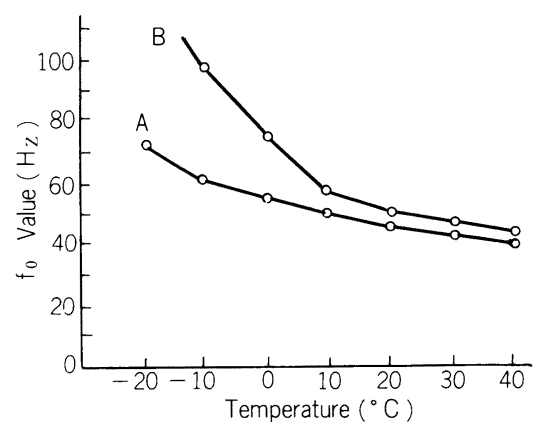

A : chrome collagen edge (speaker A) $\mathrm{B}:$ cotton cloth edge (speaker B)

図 5 Temperature Dependency of $f_{0}$ Value of Speaker A Using Chrome Collagen Edge, Compared with Speaker B Using Cotton Cloth Edge ${ }^{4)}$

表 2 合成繊維紙の性質の一例 ${ }^{5)}$

\begin{tabular}{|c|c|c|c|c|c|c|c|c|}
\hline \multirow{2}{*}{ 性 } & \multirow{2}{*}{ 質 } & \multicolumn{2}{|c|}{ 各 } & 種 & 繊 & 維 & \multicolumn{2}{|c|}{ 紙 } \\
\hline & & 木材パルプ & レーヨン & アセテート & ナイロン & ビニロン & テトロン & アクリル \\
\hline 水漬伸度 & $(\%)$ & 0.29 & 0 & 0.15 & 1.20 & 0.98 & 0.0 & 0.0 \\
\hline 柔 軟 度 & $(\mathrm{mg})$ & 350 & 700 & 420 & 170 & 450 & 670 & 330 \\
\hline 比引裂度 & & 80 & 190 & 230 & 350 & 290 & 240 & 250 \\
\hline 引張強さ $(\mathrm{kg}$ & $\left.\mathrm{mm}^{2}\right)$ & 3.3 & 4.8 & 4.2 & 4.5 & 7.0 & 2.2 & 2.6 \\
\hline 吸水度 $(\mathrm{mn}$ & 10分） & 2 & 13 & 2 & 0 & 7 & 0 & 0 \\
\hline 吸油度 & （秒） & 420 & 40 & 3,600 & 1,500 & 3,600 & 3,600 & 3,600 \\
\hline 耐 折 度 & (回) & 19 & $10,000<$ & 520 & 3,500 & $10,000<$ & 70 & 35 \\
\hline 弾性回復率 & $(\%)$ & 24 & 46 & 33 & 91 & 25 & 68 & 67 \\
\hline
\end{tabular}


図 6 はポリオレフィン系合成パルプのような親油性 絾維とセルローズ系の親水性パルプを混抄した紙に, さらに加工した油・水分離フィルターは親油性繊維に 油の小滴が吸着され，段々に成長してくると，親水性 馀維に阻害されて付着力が衰え，かつ浮力も大になり， 油滴は浮上し凝集分離します。表 $3 ， 4$ はフィルター の組成を, 図 7 は分離の効果を, 表 5 は経済的効果の 一部を示しております。

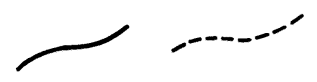

吸水性繊維吸油性瀻維
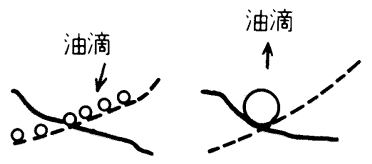

図 6

表 3 試作フィルター №.4フィルターの素材6)

4-1, セルロース系パルプコットン (ボロ), ポリオレフィン系合成パルプ

SWP E $400=1: 1$

$4-2$, ポリオレフィン采合成パルプ シンパル， SWP E 400, セルロース系パルプ コットン(ボロ), $=1: 1: 3$

バインダー PVA 系接着ファイバー VPE-105-2 3\% 分散劑 ポリエチレンオキサイド アルコックス $2 \mathrm{ppm}$ フィルター強化 $160^{\circ} \sim 170^{\circ} \mathrm{C}$ 1分, ワイヤーマー ク利用, ニードルパンチ, 部分的熱 融着含浸率 $100 \% \quad 80 \sim 90^{\circ} \mathrm{C}$ 予熱 乾燥 $110 \sim 120^{\circ} \mathrm{C} 2$ 分, セッ卜

表 4 試作フィルターN No. 4 の油水分離機能首 ${ }^{6)}$

(A) 水不溶性吸水ゼル合成物の適用 吸水性ゲルポリマー アクアプレンL710 $\quad 15 \% \quad 50 \mathrm{~g}$ フッ素系集油剤 アデカフローF K $10025 \mathrm{~g}$ \begin{tabular}{cl} 
シリコン系ポリマー トーレシリコン & $10 \% \quad 2 \mathrm{~g}$ \\
\hline トルエン & $500 \mathrm{cc}$
\end{tabular} スプレー法 $100 \%$ 紙 (Wet) $80^{\circ} \sim 90^{\circ} \mathrm{C}$ 乾燥

(B) 紙層内重縮合法 (変法)

$\mathrm{N}$ ーメチロールアクリルアミド : アクリルアミド $=3: 1$

既重合物 $5 \%$

$500 \mathrm{ccc}$

$\mathrm{N}$ ーメチロールアクリルアミドモノマー $5 \mathrm{~g}$

ヒドロキシエチルセルロース $(1 \%) \quad 500 \mathrm{ccc}$

フッ素系撥油剂 A G $5205 \%$

$30 \mathrm{ccc}$

フッ素系集油剤 アデカフローF K $1006 \quad 1 \mathrm{~g}$

ステアリン酸系親油剤 キロンC $1 \%$ 5 c.c.

過硫酸アンモニウム $2 \mathrm{~g}$

塩化アンモニウム

$2 \mathrm{~g}$

含浸法, 100\% 紙 (Wet)

$80 \sim 90^{\circ} \mathrm{C}$ 予熱乾燥 $110^{\circ} \mathrm{C}, 2 \sim 3$ 分セット

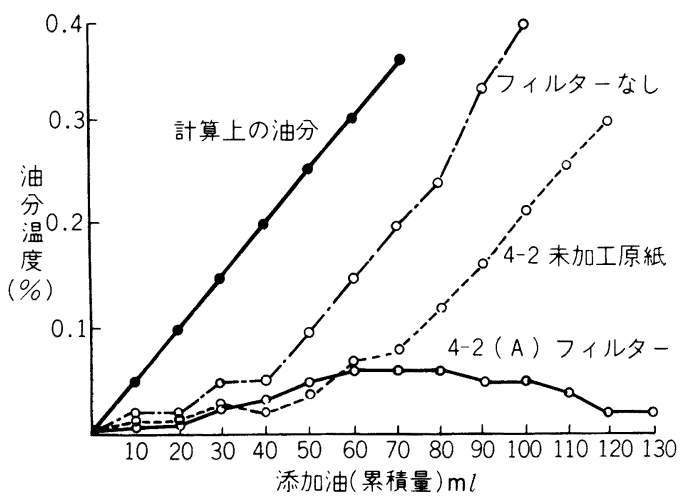

図 7 連続油添加と連続濾過 ${ }^{6)}$

表 5 経 済 性

a) 更新 (脱脂液交換) 回数及び廃液処理費 ${ }^{7}$

\begin{tabular}{c|c|c}
\hline & 導 入 前 & 導 入 後 \\
\hline 回数 $/$ 月 & 8 & $0.5(1$ 回 $/ 2$ か月 $)$ \\
\hline 月間所要時間 & 8 時間 $/ 1$ 人 & 0.5 時間 $/ 1$ 人 \\
\hline 廃 液 処 理 費 & 120,000 円 $/$ 月 & 7,500 円 $/$ 月 \\
\hline
\end{tabular}

これらのフィルターを組み込んだ油・水分離機が約 800 台稼動中ときいています。

-㵶維の集合体（2 次元の展開物）としての機能

気孔（穴）の機能の利用

穴の大きさ，分布のコントロールが容易になったた め, 滅菌用ガスは透すが菌は透さない……滅菌紙

湿熱も可能な熱交換機『ロスナイ』……目8 に示すよ うに，金属板のかわりに樹脂加工した紙を用いた熱交 換機で, 表 6 のごとく冬乾燥せず, 夏湿気を取る効果 があり三菱電機の業務用エヤコンに組み込まれて活躍 しています。

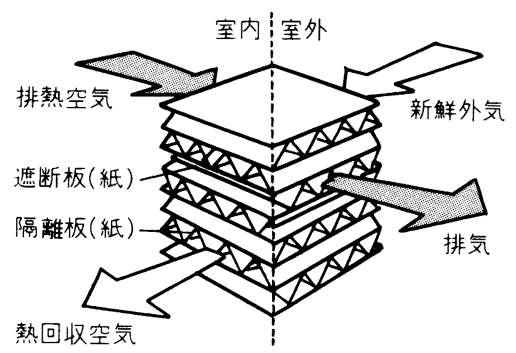

図 8 
表 6 紙の気孔を利用した熱交換機ロスナイの効率と特長 ${ }^{8)}$

\begin{tabular}{|c|c|c|c|c|c|c|c|}
\hline & & & & & ロスナイ & 顕熱交換機 & 一般換気扇 \\
\hline \multirow{2}{*}{ 熱交換率表 $(\%)$} & \multirow{2}{*}{\multicolumn{4}{|c|}{$\begin{array}{l}\text { 度（顕熱） } \\
\text { 度（潜熱） }\end{array}$}} & 75 & 75 & 0 \\
\hline & & & & & 65 & 0 & 0 \\
\hline \multirow{8}{*}{$\begin{array}{l}\text { 熱交換後の換気 } \\
\text { の温度と湿度 }\end{array}$} & \multirow{4}{*}{ 夏 } & \multicolumn{3}{|c|}{ 室内 外気 } & & & \\
\hline & & 乾球温度 ${ }^{\circ} \mathrm{C}$ & 26 & 32 & 27.5 & 27.5 & 32 \\
\hline & & 相対湿度 \% & 50 & 70 & 62 & 91 & 70 \\
\hline & & 回収全熱量 & \multicolumn{2}{|c|}{$\mathrm{kcal} / \mathrm{kg}$} & 636 & 132 & 0 \\
\hline & \multirow{4}{*}{ 冬 } & \multirow{4}{*}{$\begin{array}{l}\text { 乾球温度 }{ }^{\circ} \mathrm{C} \\
\text { 相対湿度 } \% \\
\text { 回収全熱量 }\end{array}$} & \multicolumn{2}{|c|}{ 室内 外気 } & \multirow[b]{2}{*}{15} & \multirow[b]{2}{*}{15} & \multirow[b]{2}{*}{0} \\
\hline & & & 20 & 0 & & & \\
\hline & & & & 50 & 52 & 19 & 50 \\
\hline & & & \multicolumn{2}{|c|}{$\mathrm{kcal} / \mathrm{kg}$} & 696 & 432 & 0 \\
\hline
\end{tabular}

換気量 $100 \mathrm{~m}^{3} / \mathrm{h}$ 空気比重 $\gamma=1.2 \mathrm{~kg} / \mathrm{m}^{3}$

フィルター

エヤーフィルターはクリーンルームの急増に従って 伸長を続けており, 特に高性能・超高性能フィルター (HEPA) は繊維が細いため乾式では薄層化が困難で 湿式法が適しており，その他オイルフィルターや, 同 じく孔を利用した有毒ガス・においの吸着紙も台頭し ています。

そのほか䋐維の電気的性質を利用した絶縁紙, 導電 紙や，䋐維に感応基をつけた紙などが注目されていま す。例えば，住友化学が製造している分析用ろ紙 “工 クスパピール”は重金属を分析する時間と手間が省け るための機能をかわれて $42 \mathrm{~mm}$ の直径のものが 300 〜 400 円で売られております。これを $1 \mathrm{~m}^{2}$ に換算しま すと 520 枚位とれるので約 20 万円になり, 上質紙 $1 \mathrm{t}$
の価格と同じであります。

また人工皮虑や人工臓器などに使用される生体親和 性繊維や, 活性炭繊維のような吸着能践維なども注目 されます。図 9 は 4 半世紀の間の紙用の化合緎維およ び勒皮繊維の使用量で,こうぞは昭和 49 年に統計にか からなくなり, みつまたも紙幣の関係で僅かに留まる のみになり, 昭和 59 年には合成繊維がビスコース繊維 を抜いてトップになり, 現在は $6000 \mathrm{t}$ に達し, 板紙用 を加えると約 $10000 \mathrm{t}$ の合成繊維が使用されておりま す。

図中の縦線は機能紙研究会での発表件数で, 生産が 増加する数年前に多数の発表が認められます。

現在は無機繊維紙の発表が多数で, また機能紙の加 工や利用に関する報告も増加の傾向にあります。

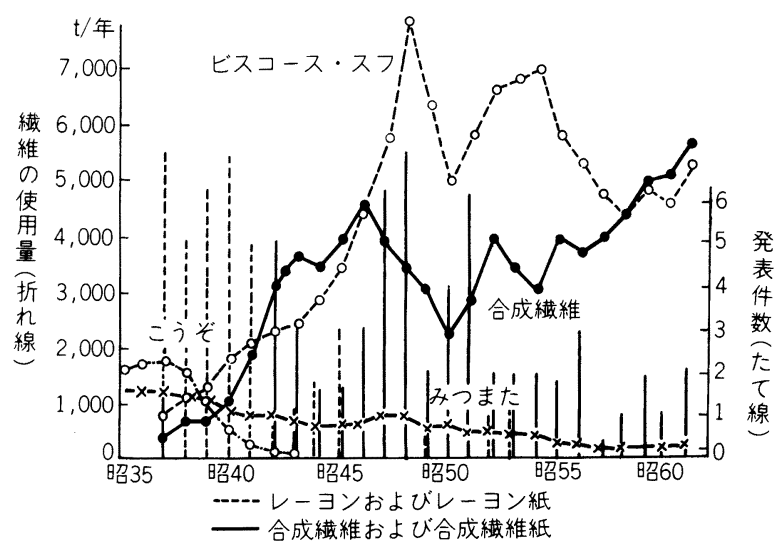

図 9 紙用化合繊維の使用量および機能紙研究会での 発表件数 
表 7 Inflated Viscose Rayons and Their Properties ${ }^{9)}$

\begin{tabular}{|c|c|c|c|c|c|}
\hline $\begin{array}{l}\text { Cross } \\
\text { Section }\end{array}$ & Name & $\begin{array}{c}\text { Water } \\
\text { Imbibition } \\
\%\end{array}$ & $\begin{array}{c}\text { Dry } \\
\text { Tenacity } \\
\text { gms./den }\end{array}$ & $\begin{array}{c}\text { Dry } \\
\text { Extension } \\
\% \\
\end{array}$ & Comments \\
\hline 8 & $\begin{array}{l}\text { Standard } \\
\text { Rayon. }\end{array}$ & $90-100$ & $1 \cdot 9-2 \cdot 5$ & $18-30$ & $\begin{array}{l}\text { Uninflated rayon for } \\
\text { comparison. }\end{array}$ \\
\hline & - & 110 & - & -1 & Not commercial. \\
\hline & Viloft & $120-140$ & $2 \cdot 2-2 \cdot 0$ & $13-15$ & $\begin{array}{l}\text { High bulk cotton-like } \\
\text { textile fibre. }\end{array}$ \\
\hline & & $150-16$ & $2 \cdot 0$ & $20-25$ & $\begin{array}{l}\text { Self bonding fibre for wetlaid } \\
\text { non-wovens. Not commercial. }\end{array}$ \\
\hline & DM1 & $160-18$ & $1 \cdot 4-1 \cdot 8$ & $20-25$ & $\begin{array}{l}\text { Self bonding fibre for quality } \\
\text { papers. Not commercial. }\end{array}$ \\
\hline & $\begin{array}{l}\text { Super } \\
\text { Inflated } \\
\text { Fibre. }\end{array}$ & $190-350$ & $1 \cdot 0-1 \cdot 4$ & $30-50$ & $\begin{array}{l}\text { Highly absorbent, opaque } \\
\text { and bulky fibre for non } \\
\text { Wovens. }\end{array}$ \\
\hline
\end{tabular}

表 8 織物の摩擦係数 $(\text { タフタ })^{10)}$

\begin{tabular}{|c|c|c|c|c|c|c|c|c|}
\hline $\begin{array}{l}\text { 瀻 } \\
\end{array}$ & & 1 & ン & & \multicolumn{2}{|c|}{ ポリエステル } & 絹 \\
\hline 断面形状 & 0 & $\Delta$ & 0 & $\vartheta$ & $\Omega$ & 0 & $\Delta$ & $\varnothing$ \\
\hline 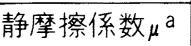 & 0.39 & 0.3 & 0.44 & 0.48 & 0.45 & 0.25 & 0.45 & 0.59 \\
\hline 力摩擦係数 $\mu \mathrm{d}$ & 0.31 & 0.28 & 0.35 & 0.39 & 0.37 & 0.22 & 0.39 & 0.47 \\
\hline
\end{tabular}

合成繊維の紙への使用量の増加は年率約 $18 \%$ に達 しております。今後，機能紙の原料として注目される ものに異形断面瀻維, 極細纎維, 高抗張力・高弾性率 繊維などがあります。

異形断面繊維は，現在はシルキーライクや麻様夕ッ 千など高級衣料材料として利用されていますが，バル キ一性や光沢を紙に与えることが可能で，紙や不織布 への使用も近いと考えられます。表 7 はビスコース レーヨンの, 表 8 と図 10 は合成纎維の異形断面繊維 で，押出しの口金の形状を変えるだけで容易に異形断 面が得られております。

極細纎維は合成皮革用として開発された従来の繊維 の $1 / 10 \sim 1 / 100$ の径の纎維で，現在は相当高価につき ますが, 感触を重んずる紙や特殊フィルター材料とし て注目されます。

高抗張力・高弹性率繊維は耐熱性も兼ねた芳香族ポ リアマイド纎維などがありますが, 現在の繊維の 10 倍 以上の強度を有するポリオレフィン系の繊維も開発さ れつつあり，紙への応用も考えておく必要があります。

このほか臭い消し繊維やアマロファス金属繊維など

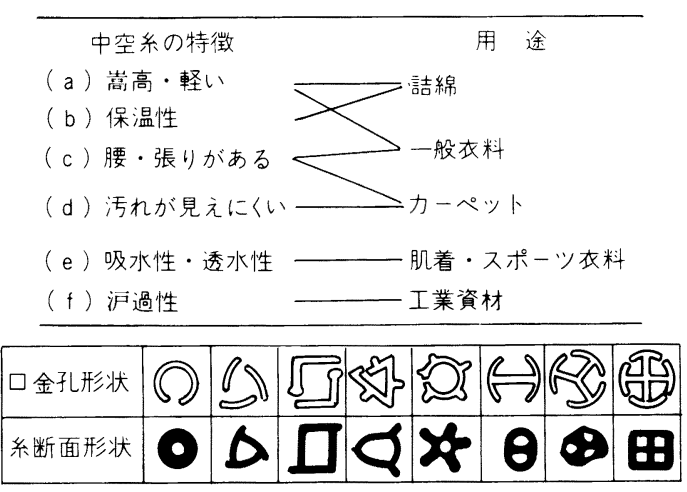

図 10 口金孔形状と糸断面形状

も機能紙の材料として，魅力ある存在であります。 - 二次加工による機能性の付与

繊維自体の機能, 紙の空孔の機能のほかに, 二次加 工による機能性の付与も重要で導電性, 絶縁性, 難燃 性, 透明性, 感光性, 磁気記録性, 耐水性, 撥水性, 消臭性, 自己粘着性, 接着性, 其他いろいろな性質が 加工により与えられています。表 9 はニッケル・コバ 
表 9 無電解メッキ紙の特性 ${ }^{11)}$

\begin{tabular}{|c|c|c|c|c|c|c|c|c|}
\hline & 紙 ${ }^{a)}$ & メッキ金属 & メッキ部分 & メッキ条件 & $\begin{array}{l}\text { 金属析出量 } \\
(\mathrm{g} / \mathrm{g} \text { 滤紙 }\end{array}$ & $\begin{array}{l}\text { 表面抵抗 } \\
\left(\Omega / \mathrm{cm}^{2}\right)\end{array}$ & $\begin{array}{l}\text { 飽和磁束 } \\
\text { 密度 }(G)\end{array}$ & 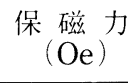 \\
\hline No. & $5 \mathrm{~A}$ & $\mathrm{Ni}$ & 全 体 & 室温, $1 \mathrm{hr}$ & 0.87 & 0.20 & 414 & 130 \\
\hline No. & & $\mathrm{Ni}$ & 表 面 & 室温, 10min & 0.08 & 1.3 & & \\
\hline No. & & $\mathrm{Ni}$ & 内 部 & 窒温, $2 \mathrm{hr}$ & 0.27 & $50^{\text {b) }}$ & & \\
\hline No. & $5 \mathrm{~A}$ & Co & 全 体 & $90^{\circ} \mathrm{C}, \quad 1 \mathrm{hr}$ & 0.63 & 2.4 & 1,560 & 165 \\
\hline No. & $5 \mathrm{~A}$ & $\mathrm{Cu}$ & 全 体 & 室温, 5min & 0.74 & 0.04 & & \\
\hline
\end{tabular}

a) 東洋滤紙製, 厚さ： $0.22 \mathrm{~mm}$ (No. $5 \mathrm{~A}), 0.26 \mathrm{~mm}$ ( No.2)

b) B 5 版の対角線に沿った抵抗值（単位 $\Omega$ )

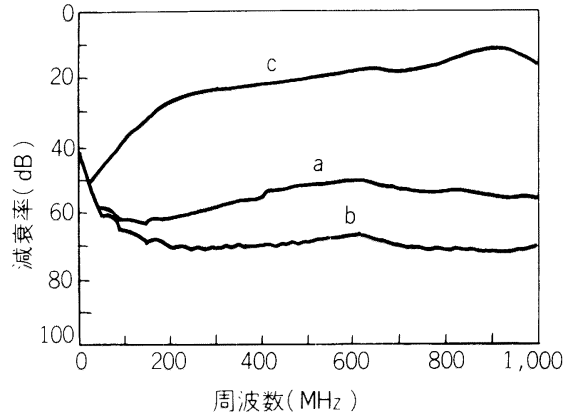

図 $11 \mathrm{Ni}$ メッキした濾紙の電磁波シールド効果 ${ }^{11)}$ (電界)

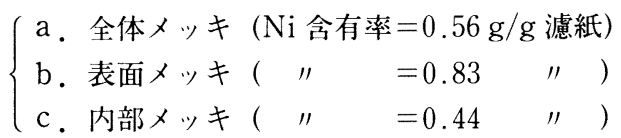

ルト，銅などを無電解メッキした紙の電気的・磁気的 性質で, 図 11 は電磁波シールド効果であります。

\section{2. 新素材としての機能紙}

尖端技術の展開に対して機能紙の果たす役割は重要 で，その主なものを部門別に列挙すると

$$
\text { (a) エレクトロニックス関連紙 }
$$

導電紙, 電波遮蔽紙, 絶縁紙, 耐熱紙, 断熱紙, 無 塵紙, 情報産業関連紙

(b) バイオ関連紙

酵素固定化用紙, 育苗紙, 吸着紙, 防虫紙, 遮光紙, 脱臭紙, フィルターペーパー

(c) メディカル関連紙

人工皮膚, 創傷被覆材, 絆創膏基布, サージカルテー プ, 経皮吸収剂基布, 診断用テスト紙, 滅菌紙, 感染 防止用フィルター, 手術衣…例えばDEXTEX, ASSURE (テトロン, ナイロンなどの合成繊維を添加 して耐摩擦性, ドレイプ性, 柔軟性縫目強度を強め,
バクテリア透過阻止性・静電防止などの処理をしてい る。などがあります。

メディカル関連紙のうち, 使い捨ての医療用不織布 (DMN)について述べると表 10 はその主な製品で, 図 12 はアメリカにおける DMN の年間売上高であり， 1970 年からの 15 年間に 8 倍以上の伸びを示していま す。DMN は安価に製造する必要上からその殆どが湿 式法によっています。

表 11 はアメリカおよび西欧の全不織布の製造工程 別の推定生産量で, 米, 欧ともに乾式>スパンボンド> 湿式の順に減少しています。但し目付けはスパンボン ド>乾式 > 湿式の順であるので，面積に換算すれば， 生産量の差は相当に接近してきます。図 13 は湿式と乾 式の伸び率の比較で, 米・欧ともに湿式の伸びが著し いことが判かります。

またこれからも一層の伸長が予想される, フィル ターペーパーについても，微小物質を濾過するために は, 細い繊維のウエブを作る必要があり，乾式法では 吹きとんでしまい地合も悪く，クリーンルームやメ ディカル用使い捨て物資の増加に従って, 湿式不織布 の需要は今後とも上昇するものと考えられます。

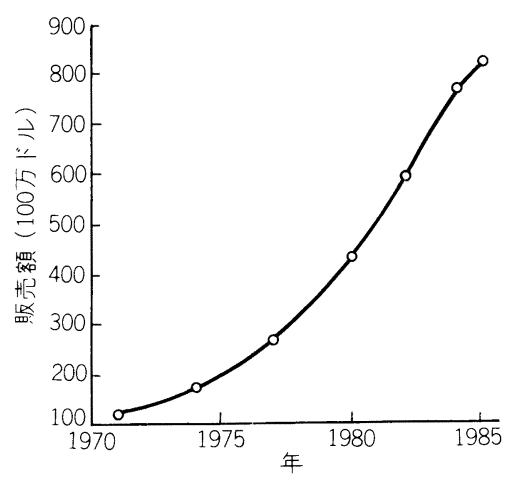

図 12 アメリカにおける DMN の年間販売額 ${ }^{21}$ 


稲垣寛

表 10 医療用ディスポーザプル・ペーパー製品

\begin{tabular}{|c|c|c|}
\hline \multicolumn{3}{|c|}{$\begin{array}{l}<\text { 一般医療及び看護用具> } \\
\end{array}$} \\
\hline インジケーター & エプロン & オムツ \\
\hline ガーゼ & カップ(検体入れ) & カバー \\
\hline 眼 帯 & キャップ & 検查衣 \\
\hline シーツ & 人工鼻 & テープ(絆創膏) \\
\hline $\mathrm{T}$ 字带 & トレー & 膿 盆 \\
\hline バッグ & パット(綿) & 腹 带 \\
\hline ギブス包帯 & マウスピース & マスク \\
\hline \multicolumn{3}{|l|}{ <麻酔及び手術室用具 $>$} \\
\hline ガウン & 靴用カバー & キャップ \\
\hline タオル & 対極板 & テープ \\
\hline ドレープ (覆い布) & マスク & \\
\hline \multicolumn{3}{|l|}{$<$ 検査及び検查室用具 $>$} \\
\hline シャーレ & 電極 (心電困用など) & ラベル \\
\hline \multicolumn{3}{|c|}{$<$ 人工蔵器及び人工腎室用具 $>$} \\
\hline
\end{tabular}

表 11 製造工程別不織布推定生産量 ${ }^{12)}$ アメリカ及び西欧， 1970-1984

\begin{tabular}{|c|c|c|c|c|}
\hline \multicolumn{5}{|c|}{ (百万ポンド) } \\
\hline & 1970 & 1977 & 1982 & 1984 \\
\hline \multicolumn{5}{|l|}{ アメリカ } \\
\hline 乾 & 220 & 415 & 510 & 530 \\
\hline 湿 & 30 & 70 & 90 & 100 \\
\hline スパンボンド & 45 & 105 & 205 & 260 \\
\hline スパンレース & - & 10 & 23 & 40 \\
\hline そ の 他 & 10 & 30 & 47 & 54 \\
\hline 合計 & 305 & 630 & 875 & 984 \\
\hline \multicolumn{5}{|l|}{ 西欧 } \\
\hline 乾 & 74 & 160 & 255 & - \\
\hline 湿 & 11 & 45 & 65 & - \\
\hline スパンボンド & 5 & 78 & 160 & - \\
\hline スパンレース & - & - & - & - \\
\hline そ の 他 & 少 & 7 & 10 & - \\
\hline 合 & 90 & 290 & 490 & - \\
\hline
\end{tabular}

\section{3. 紙の未来と機能紙}

\section{1）紙の分類と産業としての特長}

紙の大きな分類として，次のように 3 つが考えられ ます。

(a) 沉用紙……新聞用紙 (文化用紙), 板紙用紙 (産 業用紙), トイレット用紙 (家庭用紙) などのような大 量生産方式の紙で, 我国の紙・板紙の全生産量

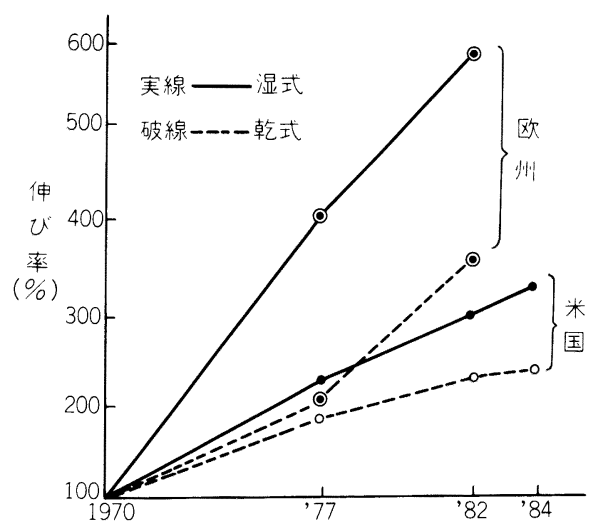

図 13 米・欧に於ける不織布の生産方式別伸び率

2000 万 強の大半は汎用紙に属し, 品質管理と合理 化と量産により利益を求好いる。図 14 は日本の, 図 15 は米国の GNP と紙の使用量・供給量との関係で GNP の伸びとよく一致した関係を示しています。

(b)機能紙……沉用紙の印刷, 包装などの既知の用 途や性能以外の，新しい機能を追求し，それらの用途 に向けられる紙で，エレクトロニクスやバイオ産業用 の新素材としての高機能性を追求する紙から，医療用 の使いすての湿式法による不織布まで，幅広い高付加 洒值紙を称しております。種々の用途に応じた機能を 必要とするため, 多種少量生産のものが多いが, 要求 される性能は厳密で, 品質管理が重要な要素になって います。 


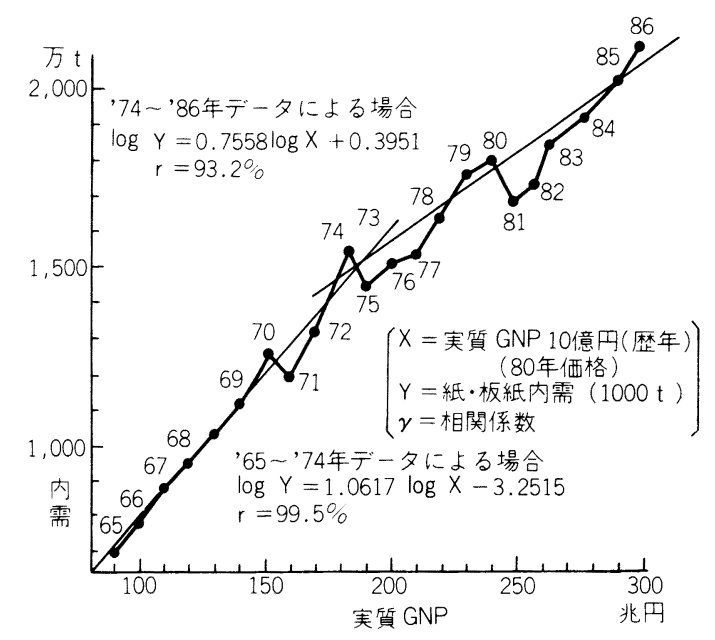

図 14 GNP (実質) と紙・板紙内需の関係 $(\text { 日本 })^{13)}$

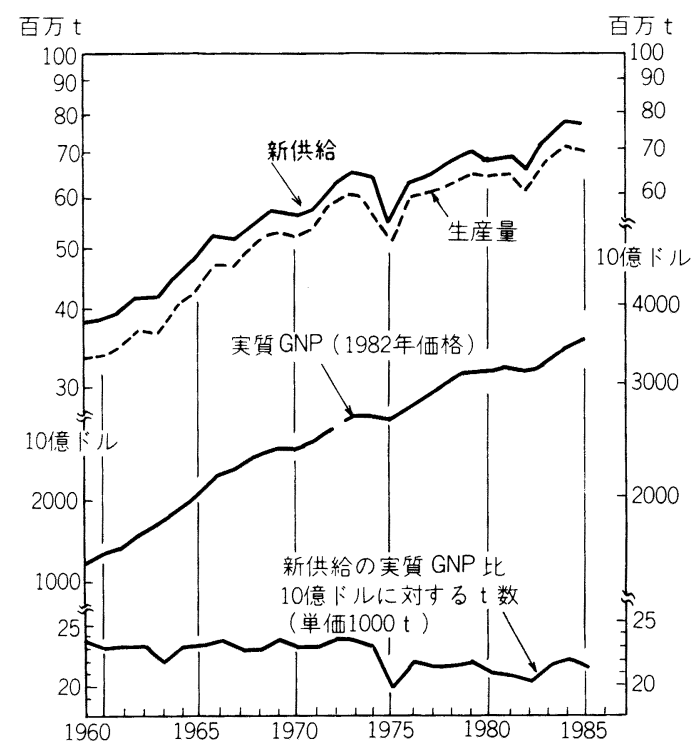

図 15 紙および板紙の供給量と GNP (米国) ${ }^{13)}$

機能紙の伸びは顕著で，その製造の際に使用される 原料繊維についても，我国で紙に使用される合成纎維 は,この 10 年間の平均伸び率 $18 \%$ であり,ささに無機 繊維などを加えると, 繊維の大きな用途に達する事は 確実であります。このほかに加工による機能化などを 考えると，この種の紙の前途は実に明るいものがあり ます。

（c）芸術紙……墨流紙，玉雲紙 (手抄き) のように 不画一で, 感性に訴える紙で, 機械抄きのファンシー ペーパーのように, 或る程度大量に生産されつつある
紙もあるが，殆どが少量生産で，いずれも”美しさ” でその価值が決められています。

天然繊維を使用しての不均一の美, 緎度の均一な化 合繊維を用いて得られる均一の美, あるいは色彩の美, 脱臭紙, 芳香紙など感覚や健康に関する紙が, ハード ウエアからソフトウエアへ,さらにハートウエア (Heartware) に至るこれからの, ゆとりの時代には” 心の機能紙”といってもよい芸術紙の需要が盛んにな ると期待されます。

このほか安全を守る紙としての Security Paper は 紙幣, 証券用紙, 小切手用紙などに, または食品の安 全を守るための特殊包装紙などにも重要性を増すもの と推測されます。

2）これからの紙と紙産業

(a) 紙および紙産業の二大分化と多様化

(1) 量産紙……レディメードが主になる紙で, 汎用 紙がこの中心で，原料から製品までを一貫した合理化 が大切で, 政策的, 機械的要素が大きい。

(2) 少量高付加価值の紙……オーダーメードが主に なる紙で, 機能紙, 芸術紙などで, 機能, 感性などが 尊重される, 技術的, 化学的要素が大きいものであり ます。

紙の生産量は繊維と違って, 緩やかに上昇しており, (1)の量産紙も合理化の推進により数量メリットを期待 することができるが，資源の少ない我国では，(2)の高 付加価值紙が重要視され, 特に機能紙は次の理由で我 国で注目されます。

原料, 資材の面……主繊維およびバインダー繊維, およびこれらの切断技術の優位性, および加工用資 材の発展。抄紙技術……長瀻維を地合上く抄く伝統 に根ざした技術および品質管理の技術。市場…… 六 イテク産業の発展と新素材の要求が大きい。立地… 良質で豊富な水などであります。

用途の多様化, 使用目的に最も適した性能の要求が強 まるに従って, 紙も多様化の傾向が顕著であり, 量産 紙は後加工により, 機能紙はより高機能の追求を, 芸 術紙はより高度の感性に応じるべく努力して応えよう としております。

（b） 21 世紀に向けての技術の展開

紙の技術の展開方式については, 次の 3 つが考えら れます。

(1) 従来の製紙技術に，新しい周辺技術を導入する。 例えばバイオテク/ロジーの利用によるパルプ材の確 保や，パルプ化，エレクトロニクス技術による紙料の 分散・抄紙機のコントロール, 新しい抄紙用, 加工用 薬品など既に実施されているものも多いが, さらに利 
用可能な異種の新技術を積極的に採り入れて, より高 能率な製紙技術の展開を計る。

(2) 新素材としての製造。例之ば耐熱紙・電磁波シー ルド紙のような機能に応じた紙を開発して, 新素材と してハイテク産業の発展を支える。

(3) 紙の技術（繊維を二次的に展開する）の展開。 纎維の技術の展開により炭素繊維や光ファイバー, 透 析用中空繊維が生まれたように，紙の技術の応用を計 る。

技術を中心に考えた場合, 横軸に物と地域との拡が りをとり, 縦軸に技術の進歩をとった場合, 紙の座標 を支える柱は，研究と教育に至ると考えます。

\section{機能の追求}

$\uparrow$

\&

“紙”(薄葉物として)ゃ技術の移転など, 地域 幅を広げる の幅を広げる

貼り合せ，複合材

१

त

研究・教育

また，製紙は次のごとく多くの科学・技術（上段） や物質 (下段) の集約ともいえます。

バイオ

」無機化学 界面科学 制御システム電気化学

上有機化学 綫維のレオロジー 液体のレオロジー

上植物学流体力学高分子化学

バルプー 加工

$$
\text { †セルロース ラテックスヤ }
$$

†合成繊維 分散剤, バインダー 继料, 其他の薬品 リグニン

パルプの製造に当たっては, 植物学・有機化学・無 機化学そして近年にはバイオケミカルも深く関わるよ うになっており, 製紙には流体科学が, 紙加工には高 分子化学や, 塗工に当たってはレオロジーなどが, ま た最近は紙の金属メッキなどのために電気化学やスッ パッタリングの技術が注目されているように，紙は総 合技術の中から生れ，また新しい技術や素材が新しい 機能紙を作りだしております。

おわりに

生活様式が多様化し，八イテク産業が高機能性材料 を必要としている時代を迎え, 新素材として, 䋊維状
物質を水中で分散させ（抄き上げ） 2 次元に展開した 機能紙に対する期待は急速に高まっております。セラ ミックにニューセラミック，ガラスにニューガラスと 同じように，紙に機能紙を加えることにより，21 世紀 への紙産業の展望をより明るいものとなることを，機 能紙研究会としてもまた紙八技術協会の一会員として も祈る次第であります。

\section{【質疑応答】}

$\mathrm{Q}$ ：ただいまのお話の中で, 紙の新しい方向というこ とで，原料の面から入る分野，製造技術の面，でき た製品を加工する分野，色々あろうかと思います。 やはり，これからの大きな重点といいますと，原料 面から考えた方がよろしいということでしょうか。

$\mathrm{A}$ ：機能紙といいますと，合成繊維紙や無機繊維紙な ど，原料をかえた紙を先ず考えられると思いますが， 私は原料, 製造方法, 加工の 3 つは同ウエイトでよ いのではないかと考えております。追求する機能を 得るためには最善を尽くす必要があり，そのために は抄紙方法や加工方法で充分なこともあります。こ れらで解決できない場合は，原料をかえることにな ク,さらに機能を向上するために抄紙方法や加工を 併用することも必要と考えます。ただ紙にとって最 も大切なのは種（たね少原料）である，という意味 ではご質問の通りとも言えますが。

\section{文献}

1）林，沢村：“障子の本” p.56，（1978）同和製紙

2) 稲垣：紙八技術夕イムス，28（5）6 (1985)

3）根岸：化学と工業, 34 (7) 82 (1981)

4) 岡村：皮革化学, 26 (3) 135 (1980)

5) D. A. Battista : "Synthetic Fibers in Papermaking” (1964)

6）久保島：機能紙研究会誌，17, 37 (1978)

7) 久保島：ibid, 19, 19 (1980)

8）三菱電機，熱交換機ロスナイ資料

9) C. R. Woodings : 1985 TAPPI Nonwovens Synposium, p.155 (1985)

10）繊維学会編：“繊維の形態”（1982）朝倉書店

11）中尾：機能誌研究会誌, 25, 37 (1986)

12) J.E. Williamson：機能紙研究会誌, 25, 50 (1986)

13）紙・パルプ1987 特集号, p.7（1987）日本製紙連 合会 